\title{
Studies on Sources and Levels of Organic Manures on Yield, Yield Attributes and Quality of Black Cumin (Nigella sativa L.)
}

\author{
M. B. Sanjeeva ${ }^{1}$, G. Gangadhar Eswar Rao ${ }^{2^{*}}$ and V. Venkatachalapathi ${ }^{3}$ \\ Research Institute on Organic Farming, University of Agricultural Sciences, GKVK, \\ Bengaluru-560065, India \\ *Corresponding author
}

Keywords

Black cumin, Organic

Manures, Bio-digester

liquid organic manure,

black cumin fixed oil

volatile oil (\%)

Article Info

Accepted:

22 July 2019

Available Online:

10 August 2019

A B S T R A C T

A field experiment entitled "studies on sources and levels of organic manures on yield, yield attributes and quality of black cumin" was conducted at RIOF, UAS, GKVK, Bengaluru during rabi 2017. The experiment was laid out in RCBD with 12 treatments replicated thrice and the cultivar used was Ajmer Kalonji-1. Results revealed that application of 125 per cent $\mathrm{N}$ equivalent through vermicompost recorded significantly higher seed yield and fixed oil yield (723 and $261 \mathrm{~kg}$ ha-1, respectively). This was attributed mainly by enhanced yield attributes like days to 50 per cent flowering (52.34), number of pods per plant (28.67), size of pods (3.00 $\mathrm{cm} 2)$ and seeds per pod (87.33), 1000 seed weight $(2.39 \mathrm{~g})$ and quality parameters like fixed oil $(36.20 \%)$ and volatile oil $(0.70 \%)$. Significantly lower yield and yield attributes, quality of black cumin was recorded in application of 75 per cent $\mathrm{N}$ equivalent through compost.

\section{Introduction}

A strong and prosperous agriculture is necessary for the economic growth and development of the country. Agriculture is one of the oldest and most prospective professions of human civilization whose success depends on soil organic matter status.

Organic farming gives major emphasis on recovery and maintenance of soil fertility and sustainable yield. Organic farming helps to improve the physical, chemical and biological properties of soil and maintains the ecological balance as well as productivity of life supporting system for the future generations.

Organic farming is gaining momentum all over the world as it addresses self-reliance in food, rural development and conservation of natural ecosystem and sustained biodiversity (Pathak and Ram, 2006). Due to increasing health consciousness in recent years, organic products have gained niche position in global food market (\$100 billion) particularly in developed countries. 
Organic manures constitute a dependable source of essential nutrients besides improving the soil physical, chemical and biological conditions. The management of nutrients in organic farming systems presents a formidable challenge, as the use of inorganic fertilizers is not permitted. Therefore, organic must optimize a range of soil, crop rotation and manure managements to ensure a nutrient supply which will guarantee optimum crop yields and minimize losses to the environment. To achieve this objective, an appreciation of the nutrient cycles in farming systems is essential which is possible through various agronomic practices i.e., crop rotation, cover cropping, application of compost, FYM, green leaf manure, crop residues, animal manure liquid organic manure and biofertilizers.

Black cumin (Nigella sativa L.) belonging to the family Ranunculaceae, is an annual herbaceous spice crop. The seeds are economically important and they contain 36 to 38 per cent fixed oil and 0.5-1.0 per cent volatile oil. The most important active compounds are thymoquinone (30-48 \%), thymohydroquinone, dithymoquinone, pcymene (7-15 \%), carvacrol (6-12\%), 4terpineol (2-7 \%), t-anethol (1-4 \%), sesquiterpene longifolene (1-8 \%) $\alpha$-pinene and thymol etc. Black cumin seeds also contain some other compounds in trace amounts. Seeds contain two different types of alkaloids; i.e. isoquinoline alkaloids and pyrazol alkaloids or indazole ring bearing alkaloids. Moreover, N. sativa seeds also contain alpha-hederin, a water soluble pentacyclic triterpene and saponin, a potential anticancer agent (Al-jassir, 1992).

Black cumin seed is an expensive spice, the seeds are used both as a seed spice and also for medicinal purposes. Essential oil of this spice is extensively used in pharmaceutical industries.

\section{Materials and Methods}

A field experiment was carried out during rabi2017 at RIOF experiment block, Gandhi Krishi Vignana Kendra, Bengaluru. Bengaluru. Soil of the experimental site was red sandy loam classified as Alfisols. Organic carbon, available nitrogen, phosphorus and potassium content of the soil were medium.

The experiment was laid out in randomized complete block design (RCBD). The experiment was laid out with 12 treatments consisting of different levels and combination of organic manures.

\section{Application of manures}

Well decomposed farm yard manure @ $7.5 \mathrm{t}$ $\mathrm{ha}^{-1}$ was applied to all the treatments considering 0.4 per cent of $\mathrm{N}$ in FYM. The farm yard manure was incorporated into the soil by using hand fork. Compost, vermicompost and biodigester manures were analyzed for their nutritive value. Compost and vermicompost was applied as a basal dose and the biodigester liquid organic manure applied in split dose according to treatments details.

The seeds of black cumin cultivar Ajmer kalonji -1 were sown at spacing of $30 \mathrm{~cm}$ wide rows at $1 \mathrm{~cm}$ depth with a seed rate of $5 \mathrm{~kg} \mathrm{ha}^{-}$

1 . The furrows were covered properly and the plots were irrigated lightly after sowing. Excess seedlings were thinned out manually 21 days after sowing and two healthy seedlings were retained per hill. The plots were irrigated lightly after sowing and thereafter at an interval of 5-6 days during the entire cropping period depending on the soil moisture conditions. Good drainage was provided to prevent water logging. Observations on days to $50 \%$ flowering yield, yield attributes \& quality were recorded at harvest. 


\section{Quality analysis}

\section{Fixed oil content}

Fixed oil content of the black cumin was determined by extracting the oil by using the method of oil extraction by soxtherm apparatus.

\section{Fixed oil yield per hectare}

The fixed oil yield per hectare was calculated on the basis of seed oil content and seed yield obtained per hectare and expressed in kilograms per hectare.

Oil yield $(\mathrm{kg}$ ha-1) $=$ Oil content $(\%) \times$ Seed yield

\section{Volatile oil content}

Volatile oil is extracted using Clevenger apparatus, its works based on the principle of hydro distillation.

$$
\text { Oil content }(\%)=\frac{\text { Weight of extracted oil }}{\text { Weight of sample }}
$$

Experimental data collected was subjected to statistical analysis by adopting Fisher's method of Analysis of Variance (ANOVA) as outlined by Gomez and Gomez (1984).

Critical Difference (CD) values were calculated whenever the ' $F$ ' test was found significant at 5 per cent level.

\section{Results and Discussion}

\section{Yield \& Yield attributes}

Application of different organic manures at different levels and their combination on days to $50 \%$ flowering was found to be nonsignificant; however application of 125 per cent $\mathrm{N}$ equivalent through vermicompost has recorded higher days for $50 \%$ flowering (52.34). (Table 2)

Whereas, different organic manures at different levels and their combination resulted in significant difference among the treatments, in which application of 125 per cent $\mathrm{N}$ equivalent through vermicompost has recorded significantly higher seed yield (723 $\left.\mathrm{kg} \mathrm{ha}^{-1}\right) \&$ stalk yield (1467 $\mathrm{kg} \mathrm{ha}^{-1}$ ) Table 1 .

This is due to increased yield attributes viz., pods per plant (28.67), seeds per plant (87.33), pod size $\left(3.00 \mathrm{~cm}^{2}\right), 1000$ seed weight $(2.39 \mathrm{~g})$ $\&$ shelling percent $(57.67 \%)$ recorded in $\mathrm{T}_{6}$ i.e, application of 125 per cent $\mathrm{N}$ equivalent through vermicompost. However, it was on par with application of 50 per cent $\mathrm{N}$ equivalent through vermicompsot +25 per cent $\mathrm{N}$ equivalent through compost +25 per cent $\mathrm{N}$ equivalent through biodigester liquid organic manure i.e., $\mathrm{T}_{11}\left(656 \mathrm{~kg} \mathrm{ha}^{-1}\right.$ seed yield; $1331 \mathrm{~kg} \mathrm{ha}^{-1}$ stalk yield) 25.00, 85.00, $2.86 \mathrm{~cm}^{2}, 2.24 \mathrm{~g} \& 55.17 \%$ yield attributes respectively) followed by application of 100 per cent $\mathrm{N}$ equivalent through vermicompost i.e., $\mathrm{T}_{5}$. Significantly lower yield and yield attributes were recorded at $\mathrm{T}_{1}$ (application of 75 per cent $\mathrm{N}$ equivalent through compost). Table $1 \& 2$

The important reason responsible for better production of yield attributes and yield could be due to the supply of nutrients in balanced amount and available form.

The increased growth in terms of plant height, branches per plant and expansion of leaf lamina provided greater sites for photosynthesis and diversion of photosynthates towards sink (pods and seed).

These results are in conformity with the findings of Darzi et al., (2012) in Pimpinella anisum and Nuthana (2017) in black cumin. 
Table.1 Influence of sources and levels of organic manures on seed yield, stalk yield, fixed oil, volatile oil and Fixed oil yield of black cumin

\begin{tabular}{|c|c|c|c|c|c|c|}
\hline Treatments & Seed Yield (kg ha ${ }^{-1}$ ) & Stalk yield (kg ha ${ }^{-1}$ ) & \multicolumn{2}{|c|}{ Fixed oil (\%) } & Volatile oil (\%) & Fixed oil yield $\left(\mathrm{kg} \mathrm{ha}^{-1}\right)$ \\
\hline T1 & 335 & 861 & \multicolumn{2}{|c|}{19.50} & 0.41 & 65 \\
\hline T2 & 403 & 940 & \multicolumn{2}{|c|}{25.20} & 0.47 & 102 \\
\hline T3 & 457 & 971 & \multicolumn{2}{|c|}{29.40} & 0.52 & 135 \\
\hline T4 & 452 & 1162 & \multicolumn{2}{|c|}{27.27} & 0.54 & 124 \\
\hline T5 & 635 & 1349 & \multicolumn{2}{|c|}{35.27} & 0.67 & 224 \\
\hline T6 & 723 & 1467 & \multicolumn{2}{|c|}{36.20} & 0.70 & 261 \\
\hline T7 & 413 & 1011 & \multicolumn{2}{|c|}{20.00} & 0.45 & 83 \\
\hline T8 & 490 & 1090 & \multicolumn{2}{|c|}{26.37} & 0.52 & 128 \\
\hline T9 & 515 & 1094 & \multicolumn{2}{|c|}{31.40} & 0.56 & 162 \\
\hline T10 & 498 & 1280 & \multicolumn{2}{|c|}{26.37} & 0.54 & 130 \\
\hline T11 & 656 & 1331 & \multicolumn{2}{|c|}{34.00} & 0.66 & 223 \\
\hline T12 & 540 & 1096 & \multicolumn{2}{|c|}{28.97} & 0.56 & 156 \\
\hline S.Em \pm & 32 & 47 & \multicolumn{2}{|c|}{1.52} & 0.017 & 13 \\
\hline $\mathrm{CD}(\mathrm{P}=\mathbf{0 . 0 5})$ & 92 & 140 & \multicolumn{2}{|c|}{4.8} & 0.051 & 37 \\
\hline \multicolumn{4}{|c|}{$\begin{array}{l}\text { T1: } 75 \% \mathrm{~N} \text { equivalent through compost } \\
\text { T2: } 100 \% \mathrm{~N} \text { equivalent through compost } \\
\text { T3: } 125 \% \mathrm{~N} \text { equivalent through compost } \\
\text { T4: } 75 \% \mathrm{~N} \text { equivalent through vermicompost } \\
\text { T5: } 100 \% \mathrm{~N} \text { equivalent through vermicompost } \\
\text { T6: } 125 \% \mathrm{~N} \text { equivalent through vermicompost } \\
\text { T7: } 75 \% \mathrm{~N} \text { equivalent through bio digester liquid organic manure (50\% as a } \\
\text { basal and } 50 \% \text { at } 30 \mathrm{DAS}) \\
\text { T8: } 100 \% \mathrm{~N} \text { equivalent through bio digester liquid organic manure (50\% as a } \\
\text { basal and } 50 \% \text { at } 30 \mathrm{DAS}) \\
\text { T9: } 100 \% \mathrm{~N} \text { equivalent through bio digester liquid organic manure }(50 \% \text { as a } \\
\text { basal and } 50 \% \text { at } 30 \mathrm{DAS})\end{array}$} & \multicolumn{3}{|c|}{$\begin{array}{l}\text { T10: } 50 \% \mathrm{~N} \text { equivalent through compost }+25 \\
\% \mathrm{~N} \text { equivalent through vermicompost }+25 \% \mathrm{~N} \\
\text { equivalent through bio digester liquid organic manure }(30 \\
\mathrm{DAS}) \\
\text { T11: } 50 \% \mathrm{~N} \text { equivalent through vermicompost } \\
+25 \% \mathrm{~N} \text { equivalent through compost }+25 \% \mathrm{~N} \text { equivalent } \\
\text { through bio digester liquid organic manure }(30 \mathrm{DAS}) \\
\text { T12: } 50 \% \mathrm{~N} \text { equivalent through bio digester liquid organic } \\
\text { manure (30 DAS) }+25 \% \mathrm{~N} \text { equivalent through compost }+ \\
25 \% \mathrm{~N} \text { equivalent through vermicompost }\end{array}$} \\
\hline
\end{tabular}


Table.2 Influence of sources and levels of organic manures on days taken for 50 per cent flowering, pods per plant, seeds per pod, pod size, 1000 seed weight and shelling $\%$ of black cumin

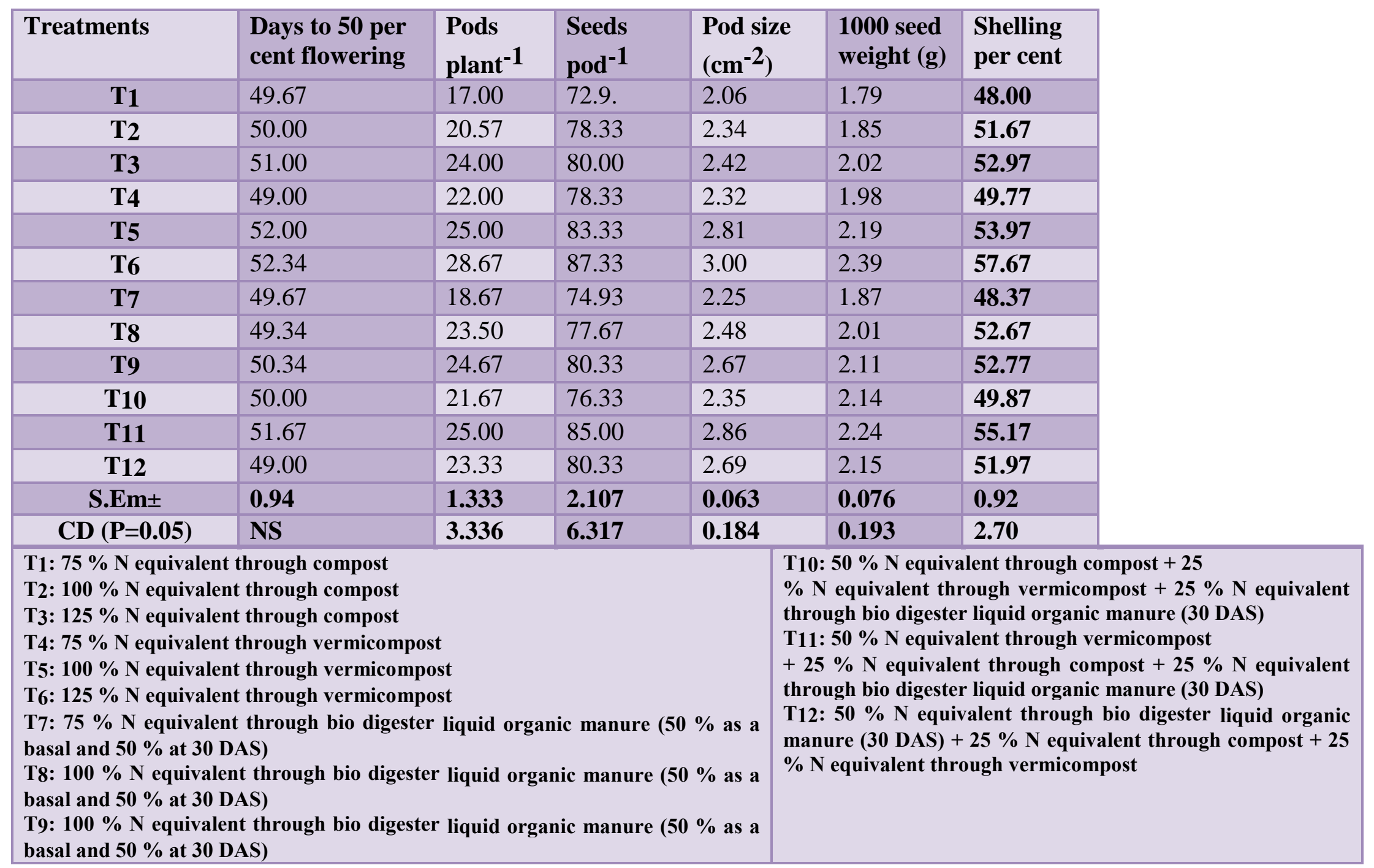


The increased photosynthesis might be due to increased biological activities of soil and mineral element absorption such as; nitrogen and phosphorus (Jat and Ahlawat, 2006).

\section{Quality parameters}

Significantly higher fixed oil content (36.20 $\%)$, volatile oil $(0.70 \%)$ fixed oil yield (261 $\mathrm{kg} \mathrm{ha} \mathrm{h}^{-1}$ ) was recorded in application of 125 per cent $\mathrm{N}$ equivalent through vermicompost. (Table 1). It was found to be on par with $T_{11}$. Significantly higher fixed oil, volatile oil and fixed oil yield obtained in application of $125 \% \mathrm{~N}$ equivalent through vermicompost, because of better growth of plant and favorable nutritional environment for the supply of nutrients in balanced form and in adequate amount and also more availability of phosphorous (Zaller, 2007), this might be attributed to the fact that phosphorus is required for production of high quality seed, since it operates in coenzymes involved in energy transfer reactions. Energy is tapped in photosynthesis in the form of adenosine triphosphate (ATP) and nicotinamide adenine dinucleotide phosphate (NADP). This energy is then used in photosynthetic fixation of $\mathrm{CO} 2$ and in synthesis of lipids and other essential organic compounds.

These results are in conformity with the findings of El deen and Ahmed (1997) in black cumin and Nuthana (2017) in black cumin

Application of 125 per cent $\mathrm{N}$ equivalent through vermicompost resulted in better yield, yield attributes and quality parameters.

It was found on par with application of 50 per cent $\mathrm{N}$ equivalent through vermicompsot +25 per cent $\mathrm{N}$ equivalent through compost +25 per cent $\mathrm{N}$ equivalent through biodigester liquid organic manure and also with application of 100 per cent $\mathrm{N}$ equivalent through vermicompost. Hence, these organic manures, liquid formulations and there combination are efficient organic substitutes for obtaining higher crop yield besides improving the nutrient status of the soil.

\section{References}

Al-Jassir MS. Chemical composition and microflora of black cumin (Nigella sativa L.) seeds growing in Saudi Arabia. 1992, Food Chem., 45: 239242.

Darzi MT, Haj Seyed Hadi MR and Rejali F. Effects of the application of vermicompost and phosphate solubilizing bacterium on the morphological traits and seed yield of anise (Pimpinella anisum L.). 2012, J. Medicinal Plants Res., 6(2): 215-219.

El Deen E and Ahmed T. Influence of plant distance and some phosphorus fertigation sources of black cumin (Nigella sativa Linn.) plants. 1997, Assiut. J. Sci., 28(2): 39-56.

Gomez KA and Gomez AA. Statistical procedures agricultural research, (2/e) an international rice research institute book. 1984, A Willey Inter Science Publication, John Willey and Sons, New York.

Nuthana G. Integrated nutrient management in black cumin (Nigella sativa L.). 2017, M. Sc. (Agri.) Thesis, Univ. Agric. Sci., Bengaluru (India).

Zaller JG. Vermicompost as a substitute for peat in potting media: Effects on germination, biomass allocation, yields and fruit quality of three tomato varieties. 2007, Sci. Hortic., 112: 191199. 


\section{How to cite this article:}

Sanjeeva M. B., G. Gangadhar Eswar Rao and Venkatachalapathi V. 2019. Studies on Sources and Levels of Organic Manures on Yield, Yield Attributes and Quality of Black Cumin (Nigella sativa L.). Int.J.Curr.Microbiol.App.Sci. 8(08): 2687-2693. doi: https://doi.org/10.20546/ijcmas.2019.808.311 